J. Product. \& Dev., 27(1): $31-40$ (2022)

\title{
EVALUATION OF CD MARKERS IN LYMPHOMA STEM CELLS BY FLOW CYTOMETRY
}

\author{
Hamada M. Fawzy*; Randa Talaat* and Hossam Fahmy** \\ *Department of Molecular Biology, Genetic Engineering and Biotechnology \\ Research Institute, University of Sadat City, Egypt. \\ ** Faculty of Medicine, Ain Shams University, Egypt \\ E.mail:dr.hamada1999@gmail.com
}

\section{ABSTRACT}

Most cancer were diagnosed by using a few simple stains and looking at the appearance of cells under the microscope.

But there were only a few types of lymphoma cancer that could easily be distinguished in this way, and it often appeared that tumors of the same cell type behaved very differently in different individuals. It was obvious that something else was going on at the molecular level to account for these differences.

As medical diagnosis progressed to the study of molecules, new techniques such as flow cytometry were devised to identify specific molecules, located on the surface of white blood cells (CD markers).

In this study was carried out to assess the relation between lymphoma stem cells and 3 from specific CD markers which are CD 19, CD23 and CD 24by using flowcytometry technique to help diagnose lymphoma cancer.

Conclusively, in this study, CD 24 marker showed high positivity in Hodgkin lymphoma disease, and can be used as a diagnostic marker in this type of haematological disease and also help in its treatment. In addition, it can help in diagnosis of Non-Hodgkin lymphoma patients. This CD19 \& CD23 can help in the diagnosis of Hodgkin lymphoma patients as these two markers showed also positivity in these cases.

Keywords: Lymphoma stem cells , CD markers, flowcytometry, CD $19, \mathrm{CD} 23, \mathrm{CD} 24$

\section{INTRODUCTION}

Cancer is a potentially fatal disease caused mainly by environmental factors that mutate genes encoding critical cell-regulatory proteins. The resultant aberrant cell behavior leads to expansive masses of abnormal cells that destroy surrounding normal tissue and can spread to vital organs resulting 
in disseminated disease, commonly a harbinger of imminent patient death (Alison, 2007).

Cancer is caused by both internal factors (such as inherited mutations, hormones, and immune conditions) and environmental/ acquired factors (such as tobacco, diet, radiation, and infectious organisms). The link between diet and cancer is revealed by the large variation in rates of specific cancers in various countries and by the observed changes in the incidence of cancer in migrating (Significance of multiple mutations in cancer, 2000).

The majority of cancers, some $90-95 \%$ of cases, are due to environmental factors. The remaining 5-10\% are due to inherited genetics. Environmental, as used by cancer researchers, means any cause that is not inherited genetically, such as lifestyle, economic and behavioral factors and not merely pollution (Anand et al., 2008)

Lymphoma is a cancer of the lymphocytes - occurs when cells grow abnormally and out of control. immune cells that normally protect you from illness. Damage to genes in these cells can sometimes lead to abnormal cell behavior which makes the cells immortal - unable to die when they should or causes sustained rapid cell division..These malignant cells then may accumulate to form tumors that enlarge the lymph nodes or spread to other areas of the lymphatic system, such as the spleen or bone marrow, or outside the lymphatic system to the skin, or mucosal linings of the stomach. Lymphoma is the most commonly occurring blood cancer, and is the third most common childhood cancer (Dillon et al., 2002).

Lymphoma is a group of blood cell tumors that develop from lymphocytes (a type of white blood cell). The name often refers to just the cancerous ones rather than all such tumors (Taylor, 2000).

The main division of mature lymphoid neoplasms has been between Hodgkin's disease, nowadays called Hodgkin lymphoma (HL), and nonHodgkin lymphoma (NHL). More than $99 \%$ of HL and approximately $85 \%$ of mature lymphoid neoplasms generally derive from lymphoid cells of the Blineage, the remainder being derived from the T/NK-cell lineage (Mitelman et al., (2008)

Stem cells are defined as cells that have clonogenic and self-renewing capabilities and differentiate into multiple cell lineages. Stem cells are found in all of us, from the early stages of human development to the end of life. Stem cells are basic cells of all multicellular organisms having the potency to differentiate into wide range of adult cells ( Potten, 1997).

The scientific researchers and medical doctors of today hope to make the legendary concept of regeneration into reality by developing therapies to 
restore lost, damaged, or aging cells and tissues in the human body. This research has opened new horizons for stem cell research (Potten, 1997).

\section{Classification of stem cells on the basis of their sources}

The easiest way to categorize stem cells is by dividing them into two types:

- Early or embryonic and mature or adult.

- Early stem cells, often called embryonic stem cells, are found in the inner cell mass of a blastocyst after approximately five days of development. Mature stem cells are found in specific mature body tissues as well as the umbilical cord and placenta after birth (Jeffrey et al., 2006).

\section{Stem cell culture:}

Growing cells in the laboratory is known as cell culture. Human embryonic stem cells (hESCs) are generated by transferring cells from a pre implantation stage embryo into a plastic laboratory culture dish that contains a nutrient broth known as culture medium. The cells divide and spread over the surface of the dish. However, if the plated cells survive, divide and multiply enough to crowd the dish, they are removed gently and plated into several fresh culture dishes. The process of repeating or sub culturing the cells is repeated many times and for many months (Ulloa-Montoya et al., 2005).

CD markers are groups of special molecules on the surface of cells in our body There are more than 250 types of CD molecules They are identified using antibodies matching molecules that will bind to the specific type of CD molecule \& also show up under microscope using antibodies in the laboratory samples from blood \& lymph nodes can be checked for CD molecules \& the type of cancer precisely determined (Sternberg et al., 2004).

Different antibodies that showed similar or identical patterns of reactivity against the panel of cell types were considered to be reacting with the same surface molecule. This clustering of antibody reactivity enabled designation of a specific CD number for a particular surface molecule. (Belov et al ., 2006).

Methods for Identification of CD Antigens Flow cytometry has been identification of a limited number of $\mathrm{CD}$ antigens on the surface of leukocytes. In this method, the leukocytes in suspension are mixed with a fluorescently labeled antibody that is specific for the extracellular portion (epitope) of a surface molecule thought to be expressed on the cells. The fluorescently labeled sample is aspirated into the flow cytometer, and the cells pass singly through a narrow aperture where a laser beam individually excites fluorescent 
antibodies bound to single cells. The emitted fluorescence is detected and data accumulates for a large number (Dunphy et al., 2004).

Stem cell markers are cell surface antigen used by scientists to isolate and identify of cancer stem cells While stem cells are best defined functionally, a number of molecular markers have been used to characterize various stem cell populations Although functions have yet to be ascertained for many of these early markers, their unique expression pattern and timing provide a useful tool for scientists to initially identify as well as isolate stem cells. This mini-review summarizes evidence regarding the roles of specific markers in defining embryonic, hematopoietic, mesenchymal /stromal, and neural stem cell populations (Delinassios, 2011).

Flow cytometry (FCM) is invaluable in the diagnosis and classification of hematolymphoid neoplasms, and in determining prognosis and monitoring response to therapy. FCM is especially suited for immunophenotypic analysis of blood, fluids (e.g., cerebrospinal fluid [CSF], pleural fluid), and aspirations of bone marrow and lymphoid tissue. FCM is also ideal in small samples where its multiparametric nature allows the concurrent staining of cells with multiple antibodies complexed to different fluorochromes, thus maximizing data obtained from few cells (Wood et al., 2006).

\section{Patients and Methods \\ Subjects:}

This study was carried out on 50 subjects: 15 Hodgkin Lymphoma diseased patients (6 females and 9 males) who in the stage of diagnosis, follow-up and treatment of the disease, 15 subjects Non Hodgkin Lymphoma (5 females and 10 males) who in the stage of diagnosis, follow-up and treatment of the disease and 20 subjects as control group consisted of (10females and 10males) who in normal case.

\section{METHODS:}

All subjects were submitted to the following:

1. Full history taking.

2. General clinical examination.

3. Laboratory investigation:

- Complete blood count.

- Measurement of serum liver function.

- Measurement of serum kidney function.

4. Main tests: Measurement of (CD 19, CD 23 and CD 24)

Every samples are collected from Peripheral blood and separation 
Then Immuno-magnetic labeling and separation of CD34+/ CD34-, Progenitor Stem Cells to isolate the stem cells then Stem Cells Proliferation , Lymphoma Stem Cells Purification and In vitro Differentiation Study. The last step Staining method of markers.

\section{RESULTS AND DISCUSSION}

All result for paints study divided to tow branch: one is a main tests results ( $\mathrm{CD}$ markers) in Table (1) that compare between three CD markers CD 19 \& CD 23 and CD 24 this marker evaluate in tow type of lymphoma (Hodgkin lymphoma \& Non Hodgkin lymphoma) this patients already diagnosis lymphoma diseased patients in follow-up stage and this results to obtain positive or negative in this stage .

Table (1) was carried out to assess the relation between lymphoma stem cells and 3 specific CD markers which are CD 19, CD 23 and CD 24 and it was performed on15 Hodgkin lymphoma diseased patients and 15 nonHodgkin lymphoma diseased patients and 20 subjects as a control group by using flowcytometry technique.

Table (1) Comparison between Hodgkin lymphoma, Non-Hodgkin lymphoma and control according to level of main tests CD markers.

\begin{tabular}{|l|c|c|c|c|c|}
\hline $\begin{array}{l}\text { Main Tests CD } \\
\text { Markers }\end{array}$ & $\begin{array}{c}\text { Hodgkin } \\
\text { Lymphoma } \\
(\boldsymbol{n = 1 5})\end{array}$ & $\begin{array}{c}\text { Non Hodgkin } \\
\text { Lymphoma } \\
(\boldsymbol{n = 1 5})\end{array}$ & $\begin{array}{c}\text { Control } \\
(\boldsymbol{n}=\mathbf{2 0})\end{array}$ & $\mathbf{x 2}$ & p-value \\
\hline CD19\% & $7(46.7 \%)$ & $0(0.0 \%)$ & $0(0.0 \%)$ & & \\
High positive & $2(13.3 \%)$ & $0(0.0 \%)$ & $0(0.0 \%)$ & 42.602 & $<0.001^{* *}$ \\
Modrate positive & $\begin{array}{c}\text { (26.7\%) } \\
\text { Weak positive }\end{array}$ & $6(40.0 \%)$ & $4(0.0 \%)$ & & \\
Negative & $0(0.0 \%)$ & $11(73.3 \%)$ & $20(100.0 \%)$ & & \\
\hline CD23\% & & & & & \\
High positive & $5(33.3 \%)$ & $0(0.0 \%)$ & $0(0.0 \%)$ & & \\
Modrate positive & $3(20.0 \%)$ & $0(0.0 \%)$ & $0(0.0 \%)$ & 41.632 & $<0.001^{* *}$ \\
Weak positive & $7(46.7 \%)$ & $4(26.7 \%)$ & $0(0.0 \%)$ & & \\
Negative & $0(0.0 \%)$ & $11(73.3 \%)$ & $20(100.0 \%)$ & & \\
\hline CD24\% & & & & & \\
High positive & $15(100.0 \%$ & $0(0.0 \%)$ & $0(0.0 \%)$ & & \\
Weak positive & $0(0.0 \%)$ & $6(40.0 \%)$ & $0(0.0 \%)$ & 63.793 & $<0.001^{* *}$ \\
Negative & $0(0.0 \%)$ & $9(60.0 \%)$ & $20(100.0 \%)$ & & \\
\hline
\end{tabular}

$x^{2}:$ Chi-square test; **P-value $<0.001 \mathrm{HS}$ 
These results agree with both (Di Raimondo et al.,2001) in CD 19 positive in lymphoma cases and Schuurman (1988) in CD23 and CD24 with my results CD23 moderate positive in Hodgkin lymphoma diseased patients and week positive in non-Hodgkin lymphoma diseased patients but CD24 Very high positive in Hodgkin lymphoma diseased patients and week positive in non-Hodgkin lymphoma diseased patients, and also, were against ( Zhang et al.,2004) in CD 23 High positive in lymphoma cases and negative in my result and Mohamed Salama et al,( 2009) CD 23 High positive 92\% in Hodgkin lymphoma diseased patients but in my paper the results of CD23 don't transgress $33.3 \%$.

This Table (1) shows highly statistically significant difference between Hodgkin lymphoma, Non-Hodgkin lymphoma and control according to level of main test CD markers.

The other Routine tests (complete blood count). Through these results, relationships are made between control and lymphoma patients (Hodgkin lymphoma, non-Hodgkin lymphoma) complete blood count contains (Hemoglobin HB \% - Red Blood Cells RBCs - Hematocrit HCT - White Blood Cells - platelets And Ddifferential of WBCs shapes) difference between Hodgkin lymphoma, non-Hodgkin lymphoma and control according to $\mathrm{Hb}$, RBCs, HCT, WBCs, Platelet, monocytes and basophils\%.

These results agree with Gersten (2021) HB are low in Hodgkin and Non Hodgkin Lymphoma about normal and Yasmeen et al. (2001).

Also, RBCs are low in Hodgkin and Non Hodgkin Lymphoma about normal WBCs are high in in Hodgkin and Non Hodgkin Lymphoma about normal Platelets are significant ddifferential of WBCs shapes are more statistically significant difference with normal control. (Neutrophils \% \& Lymphocytes \% Eosinophils \%) non-significant, But, Monocytes \% and Basophils \% are significant.

This Table (2) shows statistically significant difference between Hodgkin lymphoma, Non-Hodgkin lymphoma and control according to $\mathrm{Hb}$, RBCs, HCT, WBCs, platelet, monocytes and basophils percentage.

Conclusively, in this study, CD 24 marker showed high positivity in Hodgkin lymphoma disease, and can be used as a diagnostic marker in this type of haematological disease and also help in its treatment. In addition, it can help in diagnosis of Non-Hodgkin lymphoma patients. This CD19 \& CD23 can help in the diagnosis of Hodgkin lymphoma patients as these two markers showed also positivity in these cases. 
Table 2 : Comparison between Hodgkin lymphoma, Non-Hodgkin lymphoma and control according to complete blood count.

\begin{tabular}{|c|c|c|c|c|c|}
\hline $\begin{array}{l}\text { Complete Blood } \\
\text { Count }\end{array}$ & $\begin{array}{c}\text { Hodgkin } \\
\text { Lymphoma } \\
(n=15)\end{array}$ & $\begin{array}{c}\text { Non } \\
\text { Hodgkin } \\
\text { Lymphoma } \\
(n=15)\end{array}$ & $\begin{array}{c}\text { Control } \\
(n=20)\end{array}$ & ANOVA & p-value \\
\hline $\begin{array}{l}\mathbf{H b} \\
\text { Mean } \pm \text { SD } \\
\text { Range }\end{array}$ & $\begin{array}{c}9.81 \pm 2.65 \\
4.3-12.6\end{array}$ & $\begin{array}{c}11.44 \pm 2.38 \mathrm{a} \\
7-16.9\end{array}$ & $\begin{array}{c}13.43 \pm 1.78 \mathrm{ab} \\
9.9-16.2\end{array}$ & 11.278 & $<0.001 * *$ \\
\hline $\begin{array}{l}\text { RBCs } \\
\text { Mean } \pm \text { SD } \\
\text { Range }\end{array}$ & $\begin{array}{c}3.74 \pm 0.95 \\
1.31-4.7\end{array}$ & $\begin{array}{c}4.09 \pm 0.75 \\
2.4-5.2\end{array}$ & $\begin{array}{c}4.45 \pm 0.58 \mathrm{a} \\
3.3-5.4\end{array}$ & 3.857 & $0.028^{*}$ \\
\hline $\begin{array}{l}\text { HCT } \\
\text { Mean } \pm \text { SD } \\
\text { Range }\end{array}$ & $\begin{array}{c}30.53 \pm 7.94 \\
12.7-39.8\end{array}$ & $\begin{array}{c}34.00 \pm 5.69 \mathrm{a} \\
22-42.1\end{array}$ & $\begin{array}{c}40.19 \pm 5.25 \mathrm{ab} \\
29.7-48.1\end{array}$ & 10.656 & $<0.001 * *$ \\
\hline $\begin{array}{l}\text { WBCs } \\
\text { Mean } \pm \text { SD } \\
\text { Range }\end{array}$ & $\begin{array}{c}19.83 \pm 28.13 \\
1.69-100\end{array}$ & $\begin{array}{c}12.97 \pm 26.19 \\
0.73-107\end{array}$ & $\begin{array}{c}7.44 \pm 2.45 \\
3.9-12.7\end{array}$ & 1.488 & 0.236 \\
\hline $\begin{array}{l}\text { Platelet } \\
\text { Mean } \pm \text { SD } \\
\text { Range }\end{array}$ & $\begin{array}{c}191.80 \pm 145.01 \\
12-538\end{array}$ & $\begin{array}{c}176.93 \pm 93.88 \\
56-387\end{array}$ & $\begin{array}{c}257.20 \pm 82.83 \mathrm{ab} \\
145-412\end{array}$ & 2.800 & $0.049 *$ \\
\hline $\begin{array}{l}\text { Neutrophils \% } \\
\text { Mean } \pm \text { SD } \\
\text { Range }\end{array}$ & $\begin{array}{c}46.07 \pm 23.13 \\
2-84\end{array}$ & $\begin{array}{c}52.07 \pm 19.77 \\
5-84\end{array}$ & $\begin{array}{c}55.60 \pm 10.19 \\
35-72\end{array}$ & 1.231 & 0.301 \\
\hline $\begin{array}{l}\text { Lymphocytes \% } \\
\text { Mean } \pm \text { SD } \\
\text { Range }\end{array}$ & $\begin{array}{c}42.53 \pm 25.46 \\
13-98\end{array}$ & $\begin{array}{c}34.53 \pm 22.28 \\
9-95\end{array}$ & $\begin{array}{c}37.15 \pm 10.23 \\
22-59\end{array}$ & 0.656 & 0.524 \\
\hline $\begin{array}{l}\text { Monocytes \% } \\
\text { Mean } \pm \text { SD } \\
\text { Range }\end{array}$ & $\begin{array}{c}8.60 \pm 4.75 \\
0-18\end{array}$ & $\begin{array}{c}10.87 \pm 4.18 \\
0-31\end{array}$ & $\begin{array}{c}5.00 \pm 1.78 \mathrm{ab} \\
2-8\end{array}$ & 5.509 & $0.007^{*}$ \\
\hline $\begin{array}{l}\text { Eosinophils \% } \\
\text { Mean } \pm \text { SD } \\
\text { Range }\end{array}$ & $\begin{array}{c}2.27 \pm 2.84 \\
0-10\end{array}$ & $\begin{array}{c}1.60 \pm 2.06 \\
0-7\end{array}$ & $\begin{array}{c}2.05 \pm 1.73 \\
0-6\end{array}$ & 0.358 & 0.701 \\
\hline $\begin{array}{l}\text { Basophils\% } \\
\text { Mean } \pm \text { SD } \\
\text { Range }\end{array}$ & $\begin{array}{c}0.60 \pm 1.06 \\
0-3\end{array}$ & $\begin{array}{c}0.33 \pm 0.49 \mathrm{a} \\
0-1\end{array}$ & $\begin{array}{c}0.10 \pm 0.31 \mathrm{ab} \\
0-1\end{array}$ & 2.433 & $0.039 *$ \\
\hline
\end{tabular}

F-ANOVA test;

p-value >0.05 NS; *p-value <0.05 S; **p-value <0.001 HS

a: Significant difference between Hodgkin Lymphoma

b: Significant difference between Non-Hodgkin Lymphoma 


\section{REFERENCES}

Alison M. (2007). The Cancer Handbook, 2 Volume Set, $2^{\text {nd }}$ Edition.

Anand P, Kunnumakkara AB, Kunnumakara AB, Sundaram C, Harikumar KB, Tharakan ST, Lai OS, Sung B, Aggarwal BB (2008): "Cancer is a preventable disease that requires major lifestyle changes".

Belov L, Mulligan SP, Barber $N$ et al (2006). Analysis of human leukaemias and lymphomas using extensive immunophenotypes from an antibody microarray. Br J. Haematol , 135:184-197.

Charles and Jr. (2006). Goldthwaite Regenerative Medicine. Department of Health and Human Services. Report, August .

Delinassios J (2011): International Institute of Anticancer Research

Dillon, K.M., Hill, C.M., Cameron, C.H.S., Attanoos, R.L. \& McCluggage, W.G. (2002) Mediastinal mixed dendritic cell sarcoma with hybrid features. J. Clin. Pathol, 55: 791-794.

Dunphy, CH.(2004). Application of flow cytometry immunohistochemistry to diagnostic hematopathology. Archives Of Pathology And Laboratory Medicine; 128 (9):1004-1022.

Francesco Di Raimondo, Maher Albitar, Yang Huh (2001). The Clinical and Diagnostic Relevance of CD23 Expression in the Chronic Lymphoproliferative Disease.

Jeffrey, M. K.; M. Ponzetti and S. A. David.(2006). Stem cells An Interactive Qualifying Project Report, Submitted to the Faculty of Worcester polytechnic institute In partial fulfillment of the requirements for the Degree of Bachelor of Science.

John Zhang, David Chin (2004). CD5 and CD23 Positive Mantle Cell Lymphoma Detected by Flow Cytometry and Confirmed by FISH Study.

Mitelman F, Johansson B, Mertens F, Editors (2008): Mitelman Database of Chromosome Aberrations in Cancer.

Mohamed E. Salama; M. Rajan Mariappan ; Kedar Inamdar; Shery R. Tripp, M.T. (ASCP), Sherrie L. ;Perkins, M.D. (2009). The Value of CD23 Expression as an Additional Marker in Distinguishing Mediastinal (Thymic) Large B-Cell Lymphoma From Hodgkin Lymphoma.

Potten, C.S. (1997). Stem Cells. London: Academic Press.

Schuurman, H. J.; , L. F. Verdonck, J. Van Baarlen, and J. A. Van Unnik (1988). Immunopheno typing of non-Hodgkin's lymphoma. Correlation with relapse-free survival. 
Significance Of Multiple Mutations In Cancer (2000). Loeb KR, Loeb LA Carcinogenesis. 2000 Mar;)

Sternberg, S (2004). Diagnostic Surgical Pathology (4th Ed); Lippincott Williams \& Wilkins.

Tahira Yasmeen; Jamshed Ali, Khadeeja Khan, and Neelam Siddiqui (2019). Frequency and causes of anemia in Lymphoma patients) 2019

Taylor E. J. (2000). Dorland's Illustrated medical dictionary. (29th ed.). Philadelphia: Saunders. p. 1038. ISBN 0721662544).

Todd Gersten (2021)., (Understanding Blood Counts in Lymphoma) 2021.

Ulloa-Montoya, F; C.M Verfaillie and W. SHu (2005). "Culture systems for pluripotent stem cells". J. Biosci Bioeng., 100 (1): 12-27.

Wood B. (2006). 9-color and 10-color flow cytometry in the clinical laboratory. Arch Pathol. Lab. Med., 130: 680-690.

\section{ـالكثف عن دلالات الأورام (الأقراص المضغوطة_علامات التمايز) للخلايا. الجذعيه في الأورام الليمفاوية باستخدام طريقه التدفق الخلوي

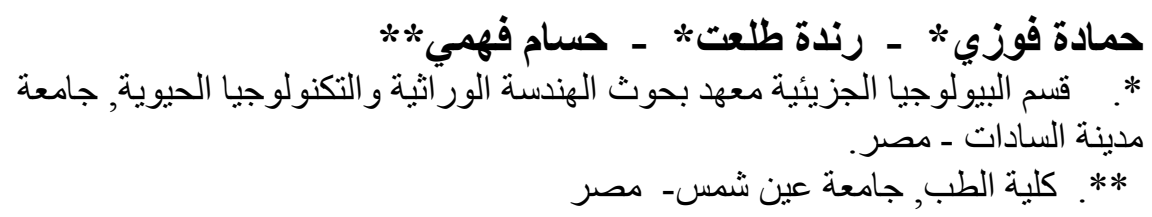

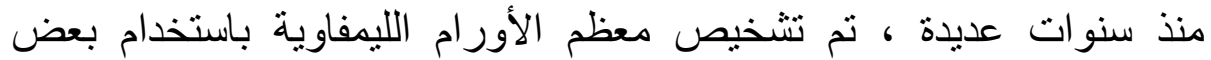

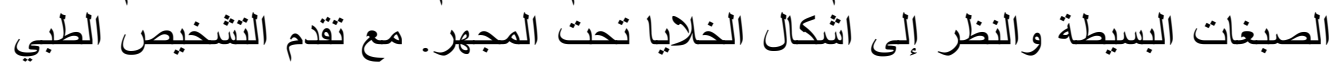
لدراسة الجزيئات ، تم ابتكار تقنيات جديدة مثل قياس التدفق الخلوي لتحديد جزيئات

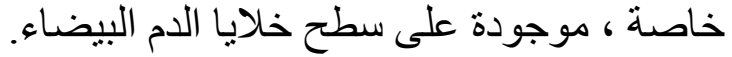

ويشار إلى هذه الجزيئات على أنها مجموعة من الاقر اص المضغوطة او (CD) علامات التمايز

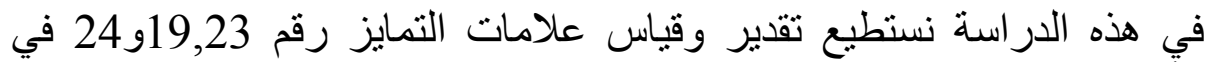

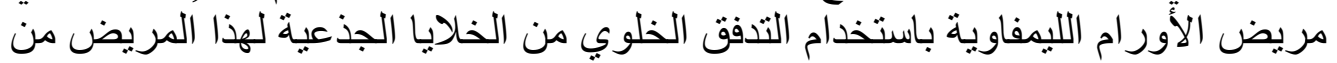

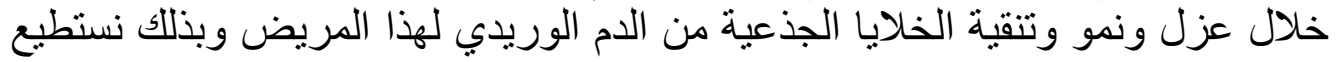

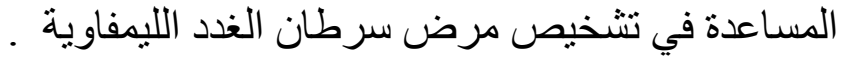


الهدف من العمل: الهدف من دراستتا هو تقييم وقياس علامات التمايز رقم 19,23و 24

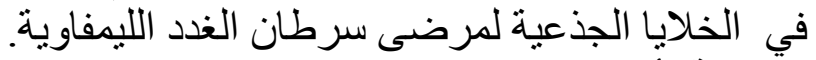

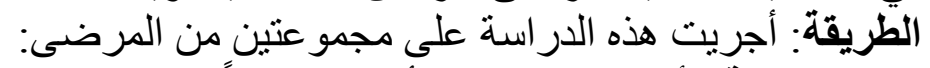

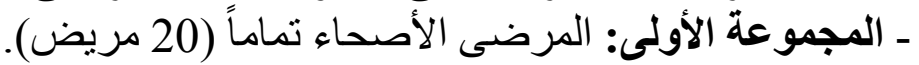

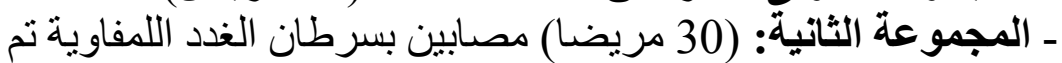
تشخيصهم و تأكيدها بو اسطة الخز عة مانية والاختبار ات الروتينية الأخرى. مقسمة إلى نوعين: 15 مرضى هو دجكين ليمفوما 15 مريض غير هودجكين ليمفوما

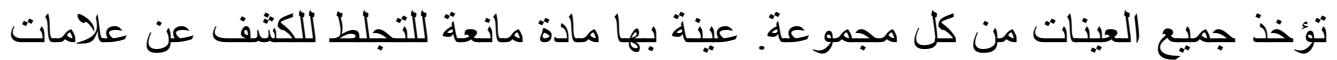
التمايز بواسطة التدفق الخلوي. و العينة الأخرى هي عينة مصلية لإجراء الاختبارات

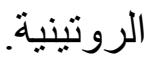
تم اختيار جميع المرضى و الاصحاء من مجمو عة مستشفيات كليو باتر ا (مستشفي القاهرة التخصصي) ، قسم السرطان في مستشفى دمرداش.

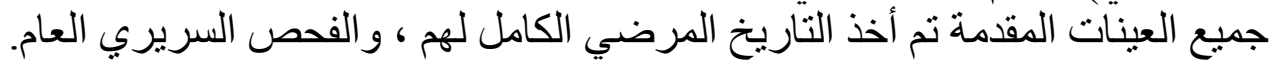
النتيجة: ظهور تباين في نتائج علامات التماييز رقم 19,23 و و24 بين مرضي سرطان النيان الغلاصد الليمفاوية تلية الخلاصة: تقييم علامات الأقراص المضغنوطة بلإعلامات التمايز) في الخلايا الجذعية الليمفاوية يمكن أن يساعد في تشخيص وعلاج مرضي سرطان الغدد الليمفاوية في

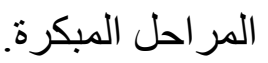

